\title{
Legal Relationship between the Supervisor of a Letter of Credit and the Beneficiary of a Letter of Credit
}

\author{
Akreditif Amiri ile Akreditif Lehtarı Arasındaki Hukuki İlişki
}

\section{Abstract}

In international trade, the seller who will send goods to other countries and the buyer who will send the price of the goods to be bought want to be sure that the other party of the contract will fulfill its debts properly. The letter of credit is an institution that aims to provide this. A letter of credit is a contract made by a person who has purchased goods, upon the submission of certain documents determined by the contract by the seller, by making a contract with a bank to ensure the payment of the debt. The supervisor of the letter of credit is the person who opens the letter of credit. The beneficiary of the letter of credit is the seller of the goods. The legal relationship between the supervisor and the beneficiary of the letter of credit, also called the basic relationship, which is generally in the nature of a sales contract, constitutes the basis of the letter of credit. Due to this basic relationship between the parties and the clause of the letter of credit in this relationship, various debts of the parties arise. In this study, the legal relationship between the supervisor of the letter of credit and the beneficiary of the letter of credit and the debts of the parties will be examined.

\author{
Fatih Ölmez \\ Arş. Gör. Dr., İstanbul Sabahattin Zaim \\ University, fatih.olmez@izu.edu.tr \\ Orcid No: https://orcid.org/0000-0001- \\ 5802-3641
}

\section{Article Type / Makale Türü \\ Research Article / Araştırma Makalesi}

\begin{abstract}
Anahtar Kelimeler
akreditif amiri, akreditiflehtarı, temel ilişki, akreditif şartı
\end{abstract}

\begin{abstract}
Keywords
supervisor of a letter of credit, beneficiary of a letter of credit, basic relationship, clause of the letter of credit
\end{abstract}

Submitted: $17 / 10 / 2021$

Accepted: $\quad 18 / 01 / 2022$
Öz

Uluslararası ticarette başka ülkelere mal gönderecek satıcı ile alacağ̊ malın bedelini gönderecek alıcı, sözleşmenin karşı tarafinın borcunu uygun bir şekilde yerine getireceğinden emin olmak ister. Akreditif de bunu sağlamaya yönelik bir kurumdur. Akreditif, mal satın almış bir kişinin, bir banka ile anlaşarak, sözleşme ile belirlenmiş belirli belgelerin satıcı tarafından ibrazı üzerine, borcun ödenmesinin sağlanmasına yönelik bir sözleşmedir. Akreditif amiri, akreditifi açtıran kişidir. Akreditiflehtarı ise malın satıcısı konumundadır. Akreditifamiri ile lehtar arasında, temel ilişki olarak da adlandırılan, genellikle satım sözleşmesi niteliğindeki hukuki ilişki akreditifin dayanağını oluşturmaktadır. Taraflar arasındaki bu temel ilişki ve bu ilişkideki akreditif şartı sebebiyle tarafların çeşitti borçları doğmaktadır. Çalışmamızda, akreditif amiri ile akreditiflehtarı arasındaki hukuki ilişki ve tarafların borçları ve bu borçlara uyulmaması durumunda ortaya çıkabilecek sonuçlar incelenecektir.

\section{Introduction}

Letter of credit is a payment method frequently used in international trade. International trade requires various assurances in terms of buyers and sellers. Since the parties are in different countries and the debts cannot be fulfilled simultaneously and mutually, each party is skeptical that the other party will fulfill its debt (Bahtiyar, 1990: 74). The seller will ship the goods to the buyer in another country but is not sure that the price will be paid. It is not under a guarantee that the goods will be shipped, although the buyer is also ready to pay the price (Bahtiyar, 1990: 74). For instance, an economic or political situation in the buyer's country may prevent money from being paid or sent to the seller on time (Tekinalp, 2009: 551). Likewise, various risks exist for the buyer. For example, the exporter may not be able to send goods for reasons such as the closure of the country's borders for a while or the embargo on that product (Tekinalp, 2009: 551). The letter of credit includes regulations that reduce such risks.

The concept of a letter of credit is defined in different ways by considering legal and economic aspects. However, there is no unity in legal definitions (Doğan, 2005: 38). According to one definition, it is an instruction given by the buyer to the bank to pay the price to the seller on behalf of the buyer in return for the delivery of certain documents (of bills representing commodities), in 
accordance with a special agreement stipulated in the purchase and sale contract (Doğan, 2005: 38). The Supreme Court, on the other hand1, is defined as a contractual relationship aiming at the payment of the sales money to the seller, in return for the submission of certain documents by the seller, upon the agreement of a person who has bought goods with a bank. The definition of the letter of credit has been made by the International Chamber of Commerce (ICC) as "...any irrevocable arrangement which, whatever its name and designation, constitutes the express obligation of the issuing bank to meet proper presentation..." in article 2 of the brochure ${ }^{2}$ No. 600, titled Uniform Custom and Practice (Kostakoğlu, 2010: 965). UCP rules are not obligatory and are applied if the parties choose it as the law to be applied to the contract (Reisoğlu, 1995: 51; Çabri, 2016: 616) ${ }^{3}$.

\section{Relationship Between the Supervisor and the Beneficiary of Letter of Credit}

The supervisor of the letter of credit is the real or legal person who opens the letter of credit and gives the letter of credit instruction. In article 2 of UCP 600, the supervisor is defined as the party requesting the opening of the letter of credit. The supervisor is on the one hand the buyer of the good or service, that is, the importer, and on the other hand, the customer of the bank (Tekinalp: 2009: 557).

The beneficiary of the letter of credit is the seller, manufacturer, supplier of the good, or the person providing the service, that is, the exporter (Somuncuoğlu, 2001: 48; Tekinalp: 2009: 558).

\subsection{Basic Relationship}

As a form of payment, the basis of the letter of credit is the contract of private law of obligations, also called the basic relationship, between the beneficiary and the supervisor of the letter of credit. It is also possible for this relationship, which is generally in the nature of a sales contract, to have the characteristics of a service or work contract (Kostakoğlu, 2010: 977). Although the condition of payment by letter of credit is mostly included in international sales contracts, the fact that the contract contains an element of foreignness is not a valid condition of the letter of credit (Erdoğan, 2000: 65; Kaya, 1995: 34)4. The legal nature of the basic relationship between the supervisor and the beneficiary is of no importance in the conditions of the letter of the credit relationship. Because the letter of credit is independent of the basic relationship between the supervisor and the beneficiary (Tekinalp: 2009: 566; Doğan, 2005: 81; Çabri, 2016: 617; Kostakoğlu, 2010: 977). The fact that the letter of credit relationship is independent of the basic relationship is a basic principle that enables the transactions to be carried out quickly (Ekici, 1995: 165). The important thing is that a valid contract has been drawn up between the parties and that a contract has been made regarding the payment of the monetary debt arising from this contract by letter of credit (Doğan, 2005; 81; Dayınlarl1, 1990: 408). Even if the basic relationship is mentioned in the letter of credit, these contracts do not concern or oblige the bank (Özel, 1991: 16). Regardless of the performance of the contract, making a payment by letter of credit depends on the fact that it is agreed that it will be performed by letter of credit, depending on the contract in question (Erdoğan, 2000: 65). Thus, the determination of the performance of the customary debt-generating contracts by means of a letter of credit is called the clause of the letter of credit in practice and doctrine (Erdoğan, 2000: 65).

In case of submission of the documents submitted in accordance with the conditions in the letter of the credit contract, the claim that the seller does not comply with the sales contract and the request for non-payment of the price will not be heard, stemming from the fact that the letter of credit contract is independent of the sale contract (Kostakoğlu, 2010: 987). It is accepted that the payment of the letter of credit may be stopped in case the debt arising from the basic relationship is not

\footnotetext{
${ }^{1}$ HGK. T. 4.11.1964-E. 1964/942-K. 1964/637, (Doğan, 2005: 38).

2 Hereafter it will be abbreviated as UCP.

${ }^{3}$ In the doctrine, some authors accept that the provisions of the UCP are in the nature of customary commercial law and that UCP rules will be applied in cases where there is no provision in domestic law, even if the parties do not refer in accordance with article 1/II of the Turkish Commercial Code (Özel, 2013: 348; Dayınlarlı, 1990: 407). For the opposite view, see (Kostakoğlu, 2010: 985; Reisoğlu, 1995: 48).

${ }^{4}$ For the opposite view, see (Göğer, 1980: 62).
} 
fulfilled at all or duly although the basic relationship and the letter of credit relationship are independent of each other in both trial practice and doctrine (Çabri, 2016: 617).

The invalidity of the basic relationship in the letter of credit does not, as a rule, remove the obligation to make payments in accordance with the letter of credit contract drawn up (Tekinalp, 2009: 622). However, in the event that both the buyer and the seller know that the basic relationship is illegal, immoral, or criminal, and the contract is invalid due to said reasons, the beneficiary's request for payment is considered as an abuse of right and payment cannot be requested based on the letters of credit opened pursuant to this relationship (Çabri, 2016: 621).

\subsection{The Clause of the Letter of Credit}

The agreement reached by the parties of the contract regarding the opening of a letter of credit for the purpose of ensuring the payment in a sale or another law of obligations relationship is called the clause of letter of credit in doctrine and practice (Kaya, 1995: 34).

It is named as the clause of the letter of credit, the clause of the letter of credit, the record of the letter of credit since it is in the content of the basic relationship. However, the clause of the letter of credit does not necessarily have to be in the master contract text or be an annex to it. It may be agreed as a contractual clause separate from the master contract but regulating its performance (Erdoğan, 2000: 66). In other words, the parties may include a provision in the sales contract regarding payment by letter of credit, or they may make a separate contract in this regard (Çabri, 2016: 618). The parties can also decide on the clause of the letter of credit orally, this is also valid. The clause of the letter of credit may be stipulated explicitly in the contract, or it may be implicitly stipulated. For example, as in the sentence "the price will be paid upon presentation of the documents and bill of lading (Tekinalp, 2009: 578). The clause of the letter of credit related to the master contract may be agreed upon implicitly, or even based on confidence in the continuous commercial relationship between the parties (Erdoğan, 2000: 66). It is also possible to deduce that the payment will be made by letter of credit by interpreting the basic relationship (Kaya, 1995: 35).

The clause of the letter of credit can be made during the establishment of the purchase-sale contract, or it can be realized separately from it, especially in the said overseas sales (Uluç, 1966: 461).

The clause of the letter of credit is usually included as a simple statement in the original contract. Expressions such as "Payment will be made by letter of credit in exchange for loading notes at bank $X$ " or "payment will be made in exchange for documents at bank X" or "the price will be paid by letter of credit" can be given as examples (Erdoğan, 2000: 66). Such abbreviated clause of letter of credit is used in practice between traders in international trade. However, the clause of the letter of credit should be clear enough to settle disputes (Erdoğan, 2000: 66).

In the clause of letter of credit, the name of the beneficiary, the amount of the letter of credit, the type and nature of the letter of credit, the opening time and the validity period of the letter of credit, a full and proper explanation of the goods subject to sale, the way and by what means these goods will be transported, and what kind of insurance is required for the goods subject to sale should be clearly stated (Kaya, 1995: 35). In addition to these records, the conditions that must be met due to the nature of the concrete case should be included in detail (Kaya, 1995: 35).

The UCP rules apply primarily to the letter of credit and although not applicable to the basic relationship, it can be used to complete and interpret the clause of the credit (Erdoğan, 2000: 67). For example, if it is not clear from the clause of letter of credit whether the letter of credit is revocable or irrevocable, the provision of Article 6 of the UCP is applied to the case by analogy and it is ruled that the letter of credit is irrevocable (Ekici, 1995: 74; Erdoğan, 2000: 67). If there is no result in understanding the clause of the letter of credit, with neither the interpretation of the contract nor the completion of the contract with $\mathrm{UCP}$, the dispute is tried to be resolved by taking into account the purpose and object of the letter of credit, especially the guarantee and payment functions (Erdoğan, 2000: 67).

The conditions of the letter of credit and the conditions of the sales contract must be the same. In the event that the conditions of the letter of credit differ from the contract of sale, the beneficiary 
must reject this letter of credit. Otherwise, it will face the claim that it accepts the change in conditions of sale (Reisoğlu, 1995: 127).

\subsection{Legal Nature of the Clause of the Letter of Credit}

The decision to make the payment by letter of credit does not directly lead to the establishment of a letter of credit relationship; this situation imposes a debt on the buyer to open the letter of credit (Çabri, 2016: 618). In a contract with the clause of the letter of credit, opening the letter of credit together with other principal debts is also a principal obligation. The clause of the letter of credit in the contract ensures that the letter of credit is a principal debt (Erdoğan, 2000: 68). The buyer undertakes to open a letter of credit against the seller with all the details as agreed in the clause of the letter of credit (Erdoğan, 2000: 68).

With the letter of the credit contract, the parties to the contract undertake mutual preperformance obligations. Pursuant to this condition, the buyer is obliged to open a letter of credit in accordance with the contract reached with the beneficiary and to notify it through the bank, as well as to pay the sale price to the beneficiary via a letter of credit (Kaya, 1995: 36). Against these obligations of the buyer, the seller undertakes to submit the agreed documents and send the goods subject to sale in accordance with the clause of the letter of credit (Kaya, 1995: 36).

It is contrary to the contract for the seller to request payment in another way, although the payment of the price is subject to the clause of the letter of credit in the contract (Tekinalp, 2009: 579). The clause of the letter of credit and the opening of the letter of credit give the supervisor of the letter of credit the opportunity to claim a payment defense in accordance with the clause of the letter of credit, in the event that the seller requests the receivable arising from the basic relationship outside the letter of credit (Tekinalp, 2009: 603). In order for the seller to claim the receivable based on the basic relationship, it must have applied to the bank in accordance with the conditions of the letter of credit and on time, and it must not have been able to obtain its receivable although it submitted the documents (Tekinalp, 2009: 603; Göğer, 1980: 65).

\subsection{The Relationship Between the Clause of the Letter of Credit and the Primary Liability \\ 1.4.1. Time of Performance}

In the contract of sale, unless the parties have agreed to the contrary or there is no contrary, both parties are under the obligation to mutually perform their acts at the same time. In international trade, the fact that the seller and the buyer are not in the same place and the place where they will perform their acts mutually is different makes it impossible for the parties to perform their acts at the same time (Erdoğan, 2000: 69). In this case, since one of the parties will pay first, there is a risk that the other party will not fulfill the obligation for the party that pays first (Erdoğan, 2000: 69).

Due to the unique nature of the letter of credit transaction, the buyer has an obligation to perform an act in advance. Although the supervisor of the letter of credit is not obliged to pay in advance, he is under the obligation to open the letter of credit. After the buyer has opened the letter of credit, which is also the main liability due to the basic relationship, in accordance with the records stipulated in the clause of the letter of credit, may request the beneficiary to send the goods subject to sale. In other words, unless the letter of credit is opened, the seller (beneficiary) may refrain from sending the goods or refuse such a request (Kaya, 1995: 37).

The buyer's obligation to open a letter of credit is also explained as a preliminary performance. Because before the seller can send the commodity, the letter of credit must be opened. In the case that the buyer does not open a letter of credit, the seller may terminate the contract according to the buyer's default rules (Erdoğan, 2000: 69). Since the opening of the letter of credit is explained as a preliminary performance obligation, the possibility that the other party (the seller) cannot deliver the goods does not result in its default (Erdoğan, 2000: 70).

\subsubsection{Barter Right}

The greatest assurance provided to the beneficiary by opening a letter of credit is that it can collect the sales price from the letter of credit bank in return for the presentation of the document after the goods are shipped to another country (Reisoğlu, 1995: 152). However, the possibility of bartering the beneficiary's receivables from the letter of credit and its debts may eliminate this assurance (Reisoğlu, 1995: 152). 
According to the view, which was pioneered by a decision of the German Federal Court and which is mostly defended in the doctrine today, the letter of the credit requirement for the buyer's performance in advance obligation to open the letter of credit is also considered a cash payment contract (Kaya, 1995: 40). In other words, even if it is not expressly agreed by the parties, the contract that the payment will be made by letter of credit also includes a barter prohibition for the buyer and the seller (Kaya, 1995: 40; Reisoğlu, 1995: 152).

If the bank that will pay the letter of credit is a creditor due to another relationship against the creditor of the letter of credit, it cannot exchange this receivable with the amount of the letter of credit. Because the amount of the letter of credit to be paid to the creditor of the letter of credit is not the debt of the bank, but the debt of the party who opened the letter of credit (Erdoğan, 2000: 72).

\subsubsection{Opening the Letter of Credit is an Act for Performance}

Opening the letter of credit or depositing the amount in the bank based on the condition in the basic relationship is not a transaction that terminates the debt relationship as a result of the buyer's fulfillment of the obligation to pay the price arising from the contract of sale, or the renewal (Kaya, 1995: 38). Only the opening of the letter of credit does not end the buyer's debt to the seller (Özel, 1991: 30). By agreeing on the clause of the letter of credit, the parties, as a rule, only guarantee the payment request of the beneficiary and have determined a payment method. For this reason, unless there is a contract to the contrary, the opening of the letter of credit does not mean performance but is considered a transaction made for the purpose of performance (Tekinalp, 2009: 563; Ekici, 1995: 74; Kaya, 1995: 38; Göğer, 1980: 65). Therefore, the beneficiary will be deemed to have collected the price only after the actual payment (Kaya, 1995: 38).

The opening of the letter of credit does not mean that the payment is made, although it is the fulfillment of the clause of the letter of credit. Both the opening of the letter of credit and the final payment with the letter of credit are the essential acts imposed on the buyer by the contract between the parties (Tekinalp, 2009: 578).

The most important consequence of considering the opening of a letter of credit as a transaction made for the purpose of the performance is that the right to claim arising from the basic relationship does not expire as a result (Kaya, 1995: 39). The claimability of the receivable arising from the basic relationship is a secondary and deferred receivable within the validity period of the letter of credit (Kaya, 1995: 39).

Since the letter of credit is not a performance but an act for performance, when the seller cannot obtain the sale price as a result of the bank's bankruptcy between the opening and payment of the letter of credit, the buyer cannot claim that he deposited the money in the bank and that therefore will not be liable (Özel, 1991: 32).

The act that replaces the performance is the bank's abstract debt commitment. In the event that the act that replaces the performance is not performed, that is, the bank does not pay the letter of credit in accordance with the abstract debt commitment, the buyer's debt to pay the price is revived (Göğer, 1980: 65). By opening the letter of credit, the buyer does not get rid of the debt. In the case that the letter of credit is not fulfilled for any reason, the buyer continues to be indebted (Göğer, 1980: 65; Reisoğlu, 1995: 152; Aydos, 2000: 86).

If the price of the letter of credit has been requested in accordance with the conditions of the letter of credit and has not been paid by the bank, the creditor can sue and follow the bank (Erdoğan, 2000: 71). Apart from this, the creditor of the letter of credit can sue the buyer who opened the letter of credit by returning to the underlying contract instead of suing for the bank. In order to do this, the creditor does not have to sue and follow the bank and return to the buyer if this is inconclusive (Erdoğan, 2000: 71).

\subsubsection{Place of Performance}

General provisions are valid for the performance of the debts of the parties due to the basic relationship, and in the event that the clause of the letter of credit is included in an international contract of sale, the domicile of the seller is the place of performance (Kaya, 1995: 41). The place of performance of the debt in the letter of credit the place where is the bank of the letter of credit that undertakes the payment of the price of the letter of credit by the letter of a credit contract or the 
confirming bank that agrees to pay the price of the letter of credit by confirming the letter of credit (Kostakoğlu, 2010: 971). The contract of the parties on the performance of the price by letter of credit does not mean that as a rule they also determine the place of performance envisaged for the basic relationship (Kaya, 1995: 41). However, the parties may agree to the contrary by placing a clear provision in the contract between them (Kaya, 1995: 41; Bahtiyar, 1990: 81).

\section{Liabilities Arising from the Clause of the Letter of Credit and the Consequences of Breach of This Liability}

\subsection{Liabilities of the Supervisor of a Letter of Credit}

\subsubsection{Liability for Opening Letter of Credit}

\subsubsection{Opening and Notification of Letter of Credit}

In a liability relationship with the clause of a letter of credit, a performance obligation must arise according to the primary liability relationship in order for the obligation to open a letter of credit to arise. If the payment debt agreed with the contract does not arise, only the letter of credit record in the contract does not create a liability in itself (Erdoğan, 2000: 73).

The opening of the letter of credit, the conclusion of the letter of credit contract between the issuer of the letter of credit and the bank, and the provision of the corresponding letter of credit do not relieve the debtor of the letter of credit. The creditor of the letter of credit must be informed of the opened letter of credit. Notification to the creditor of the opening of the letter of credit is made by the bank and thus the bank becomes obligated to the issuer of the letter of credit (Erdoğan, 2000: 74).

The liability for opening the letter of credit also includes the obligations of making and notifying it through a certain bank, in the content and time stipulated in the clause of the letter of credit (Kaya, 1995: 42). If these obligations are not performed in due time, the buyer will be deemed to have not performed the main debt imposed on itself by the contract. Due to the fact that the bank that issued the letter of credit acts as the authorized representative of the supervisor of the letter of credit and on its behalf, the risks arising from non-performance or bad performance of this debt are under the responsibility of the supervisor (Kaya, 1995: 42).

\subsubsection{Obligation to Open the Letter of Credit in Compliance with the Clause of the Letter} of Credit

The buyer and the seller may decide on the detailed provisions regarding the goods corresponding to the letter of credit in the terms of the letter of credit. If the provisions regarding the nature of the goods, documents to be submitted regarding the letter of credit, on whether to accept the letter of credit as cash or policy, these must be complied with when opening the letter of credit (Erdoğan, 2000: 74). The conditions of the letter of credit and the clause of the letter of credit agreed in the master contract must be the same. When a letter of credit is opened that does not comply with the clause of the letter of credit agreed in the master contract, the creditor of the letter of credit must immediately reject it. Otherwise, it will face the claim that the conditions for opening the basic letter of credit have been changed. If the seller does not accept this change, the letter of credit will be considered unopened (Erdoğan, 2000: 74).

Changing the conditions of an irrevocable letter of credit is possible with the participation of all parties. According to the provisions of Decision 9 of the UCP, the creditor of the letter of credit, the issuer of the letter of credit, the bank of the letter of credit, and, if any, the bank confirming the letter of credit, must agree to change the conditions of the letter of credit.

In the case that the letter of credit is not opened on time and in accordance with the stipulated conditions or contains provisions contrary to the quality of the irrevocable letter of credit, the beneficiary is obliged to notify the supervisor of the letter of credit without delay and request the necessary change to be made. If the beneficiary does not make such a request, it must be accepted that the letter of credit has been opened within the stated conditions (Kaya, 1995: 45).

\subsubsection{Letter of Credit Must Be Opened at the Appointed Time}

It is possible to clearly determine the period in which the buyer will fulfill its obligation to open a letter of credit in the contract of sale. There are also cases where the time of fulfillment of the 
buyer's obligation to open a letter of credit is not specified at all or is indicated in vague terms (Göğer, 1980: 66).

The contract of sale usually clearly states a time for opening the letter of credit. In the event that a certain date is foreseen for the opening of the letter of credit and the buyer does not open the letter of credit by this date, the buyer will be in default only with the arrival of this date, without the need for any other action. On the other hand, in other cases, the creditor must give a time and give a warning to the issuer of the letter of credit (Erdoğan, 2000: 76). The fact that a specific date is stipulated in the clause of the letter of credit does not mean that the parties also want to give the transaction a definite futures character (Kaya, 1995: 43) ${ }^{5}$. In order for a definite futures transaction to be in question, the parties must have clearly agreed that the debt must be fulfilled in the determined term, or it must be understood from the interpretation of the contract. There is no situation that requires such an interpretation of the period stipulated in the clause of the letter of credit. Therefore, it must be accepted that the parties have agreed on a certain maturity with the period stipulated in the clause of letter of credit (Kaya, 1995: 43).

\subsubsection{Default on the Liability of Opening a Letter of Credit}

If the buyer does not fulfill the obligation to open the letter of credit imposed on it due to the basic relationship on time, it will be in default (Özel, 1991: 30). There is no difference whether the default is the fault of the buyer's own actions or the fault of the correspondent bank participating in the transaction, in terms of the buyer's liability to the beneficiary. Consequently, the buyer is under an obligation to compensate the seller for damages, even if it is not its own fault. However, the buyer may claim a positive loss from the bank due to the breach of the contract between them and the bank (Kaya, 1995: 48).

If the time to open the letter of credit has not been agreed upon, the buyer must be warned by the seller for default. With the warning, a reasonable time must be allowed for the letter of credit to be opened. If the buyer does not open the letter of credit despite the warning, it is in default. If the letter of credit cannot be opened due to an impossibility, the buyer is not held responsible (Erdoğan, 2000: 80).

The fact that the letter of credit cannot be opened due to the impossibility not caused by the buyer itself only relieves it of the responsibility of not opening a letter of credit in accordance with the clause of the letter of credit; however, the obligation to pay the sales price, which is the result of the master contract, does not expire (Erdoğan, 2000: 80).

In case of default, the beneficiary will have the right to use the results related to the default directly. Accordingly, the beneficiary may demand compensation for the damage that may arise due to non-performance of the contract by withdrawing from the contract, or demand the performance of the contract and may claim compensation for the loss and damage caused by the delay (Kaya, 1995: 49).

The buyer's failure to open a letter of credit on time may also be based on reasons beyond its will. For example, it is possible that the competent authorities in the buyer's country did not allow the opening of a letter of credit (Özel, 1991: 30). In an event that came before the Supreme Court of Appeals General Assembly, a contract was made between the plaintiff Bunge S.A. and the Turkish Grain Board on the purchase and sale of wheat. The defendant TMO could not open a letter of credit as the Ministry of Finance did not allocate foreign currency on the grounds that the purchased wheat was not needed and the prices were too expensive, thereupon, the seller stated that the Turkish Grain Board was in default and filed a lawsuit seeking compensation. The court of the first instance accepted that this situation was a perfect impossibility, while the Court of Cassation stated that such an impossibility did not exist, and even if it was, the defendant was found to be defective at the birth of this impossibility. Upon the insistence of the court of the first instance in its decision, the General Assembly of Law accepted that it was not its fault that the defendant failed to get results despite all the necessary attempts according to the law. In the face of the plaintiff's counsel's request for rectification, the General Assembly of Law, which made an examination once again, decided that

${ }^{5}$ For the opposite view, see (Bahtiyar, 1990: 77). 
this time the impossibility did not occur in the case ${ }^{6}$. As clearly stated in the decision, in the event that the buyer is unable to fulfill its obligation to open a letter of credit due to legal obstacles, this must be within the scope of impossibility in order to avoid liability. At the time of the contract, if the buyer knows or needs to know that he will face such a legal obstacle, it cannot rely on the impossibility provisions (Özel, 1991: 31).

\subsubsection{Acceptance and Control of Documents}

What the documents related to the goods that the beneficiary of the letter of credit has loaded to send to the buyer consist of, its quality and quantity are clearly stated in the letter of the credit contract. These documents are generally invoices of goods, bill of loading, bill of lading, insurance documents, certificate of origin, quality certificate or laboratory reports, and customs documents (Kostakoğlu, 2010: 988; Dayınlarlı, 1990: 412).

In addition to opening the letter of credit, the supervisor of the letter of credit is under the obligation to submit the documents presented by the beneficiary and accept them if they comply with the letter of credit requirement. As a rule, this obligation is fulfilled through the letter of credit bank participating in the transaction or the correspondent bank (Kaya, 1995: 50). In the letter of credit, the payment obligation of the bank depends on the presentation of the stipulated documents. However, the bank has an obligation to examine whether the presented documents comply with the conditions of the letter of credit before making the payment. The bank examines whether the presented documents are the documents specified in the instruction, whether they meet the conditions specified in the instruction, and whether they are presented on time (Çabri, 2016: 625; Tekinalp, 2009: 584). If it is determined that the documents presented as a result of the evaluation are in accordance with the conditions of the letter of credit, the bank is obliged to pay the letter of credit; however, the bank should not make the payment if the documents presented do not meet the conditions of the letter of credit (Çabri, 2016: 626; Reisoğlu, 1995: 59). The letter of credit bank, which is responsible for accepting and paying the letter of credit documents, has to examine within a reasonable time the compliance of the documents to be presented to it by the beneficiary with the conditions of the letter of credit (Kostakoğlu, 2010: 989).

The obligation arising from the letter of credit contract ends with the rightful rejection of the letter of credit documents (Kostakoğlu, 2010: 994).

Unjustified rejection of a letter of credit documents by the bank puts the buyer in default of the creditor. In addition, the rejection of the letter of credit documents results in non-payment of the sales price. Accordingly, the debtor's default is also in question for the buyer (Erdoğan, 2000: 78; Kostakoğlu, 2010: 994). In the case that the presented documents are rejected even though they do not comply with the conditions of the letter of credit, the seller, who is the creditor of the letter of credit, is deemed to have not fulfilled its obligations (Erdoğan, 2000: 78).

As the letter of credit relationship is independent of the basic relationship, the seller's performance or defective performance of something other than what was promised does not, as a rule, affect the bank's obligation to pay. The beneficiary's formal presentation of the stipulated documents is sufficient for the bank's payment obligation to arise. However, if the beneficiary acts in breach of the good faith and this situation is determined by the letter of credit bank, the bank may refrain from paying the cost of the letter of credit (Tekinalp, 2009: 622; Kostakoğlu, 2010: 997; Çabri, 2016: 63; Reisoğlu, 1995: 233).

\subsection{Liabilities of the Beneficiary}

\subsubsection{Presentation of Documents}

It is the beneficiary's obligation to present the originals of the documents clearly specified in the letter of credit to one of the banks authorized to accept documents, provided that they are within the period of the letter of credit unless there is a contrary provision in the instruction and contract of the letter of credit (Kostakoğlu, 2010: 989).

The issue of whether the obligation of the beneficiary of the letter of credit to present the documents is a primary liability or a secondary liability that has no independent character and

${ }^{6}$ HGK T. 18.4.1984, E. 11-139, K. 426 (Özel, p. 31). 
cannot be sued separately from the primary liability is controversial. In the doctrine, there are opinions accepting that this is a primary liability, and there are also opinions accepting that it is a secondary liability ${ }^{7}$. In the accepted opinion, the consequences of non-performance would be different.

It is not possible to present documents after the expiry of the letter of credit, and documents presented after the expiry of the period must be rejected (Kostakoğlu, 2010: 989).

\subsubsection{Secondary Liabilities of the Beneficiary}

Before the letter of credit is opened or during the execution phase, the beneficiary is also liable for the performance of some secondary liabilities for the opening and use of the letter of credit, in accordance with the principle of trust. These liabilities are mostly limited to the information and explanations required for the opening of the letter of credit, but later, they are in the nature of secondary liability for the fulfillment of the contract, and they function for the provision of the right of the main claim (Kaya, 1995: 55).

One of the beneficiary's secondary liabilities is about giving information. The seller must provide the necessary information that the buyer will use to open the letter of credit. Technical terms describing what is sold are generally not used in detail in the sales contract. However, documents such as commercial invoices, transport bills, bills of lading must be used in the letter of credit. The seller must provide information about these to the buyer so that the buyer can include them in the letter of credit to be opened (Erdoğan, 2000: 85).

After the letter of credit is opened and notified to the seller, the seller must check whether the letter of credit has been opened in accordance with the conditions stipulated in the basic relationship. If the beneficiary sees that a different letter of credit has been opened than the one stipulated in the basic relationship, it should contact the supervisor of the letter of credit and report that the letter of credit has not been opened in accordance with the conditions stipulated in the basic relationship and demand its change (Doğan, 2005: 45).

\subsubsection{Consequences of the Beneficiary's Contrary to its Obligations and Liabilities}

If the creditor of the letter of credit does not submit the agreed documents within the time specified in the notice stating that the letter of credit was opened, it will be in default. At this point, the creditor's notice is not required for the debtor's default. Because, according to the 42nd article of the UCP, there must be a maturity date in order to use the letters of credit (Erdoğan, 2000: 87).

In case of default in the liability to present the documents, the seller is primarily liable for compensation for damage. In addition, the buyer also has the opportunity to withdraw from the contract on the basis that the contract is not performed at all or as required due to the reasons for not sending the goods and not presenting the documents (Kaya, 1995: 58).

In commercial transactions, if a time is determined for delivery or shipment of goods, there is a definite futures transaction. This means that the buyer does not have to grant an extension to use its optional rights in Article 125 of the Turkish Code of Obligations due to the default (Kaya, 1995: 59).

\section{Conclusion}

A letter of credit is a contract made by a person who has purchased goods, upon the submission of certain documents determined by the contract by the seller, by making a contract with a bank to ensure the payment of the debt. The legal relationship between the supervisor and the beneficiary of the letter of credit, also called the basic relationship, which is generally in the nature of a sales contract, constitutes the basis of the letter of credit. The legal nature of the basic relationship between the supervisor and the beneficiary is of no importance in the conditions of the letter of the credit relationship. Because the letter of credit is independent of the basic relationship between the supervisor and the beneficiary. Due to this basic relationship between the parties and the condition of the letter of credit in this relationship, various debts of the parties arise. The creditor of the letter of credit must be informed of the opened letter of credit. The liability for opening the letter of credit also includes the obligations of making and notifying it through a certain bank, in the content and

${ }^{7}$ For these comments, see (Kaya, 1995: 52). 
time stipulated in the condition of the letter of credit. If the buyer does not fulfill the obligation to open the letter of credit imposed on it due to the basic relationship on time, it will be in default. It is the beneficiary's obligation to present the originals of the documents clearly specified in the letter of credit to one of the banks authorized to accept documents, provided that they are within the period of the letter of credit unless there is a contrary provision in the instruction and contract of the letter of credit. If the creditor of the letter of credit does not submit the agreed documents within the time specified in the notice stating that the letter of credit was opened, it will be in default.

\section{References}

Aydos, O. S. (2000). Akreditif, Ankara, Turhan Kitabevi.

Bahtiyar, M. (1990). Akreditif ve Milletlerarası Özel Hukukta Doğurduğu Sorunlar. Banka ve Ticaret Hukuku Dergisi, 15(3), 71-88.

Çabri, S. (2016). Akreditifte Temel İlişkiden Doğan Borcun Hiç veya Gereği Gibi İfa Edilmemesinin Akreditif İlişkisine Etkisi. Marmara Üniversitesi Hukuk Fakültesi Hukuk Araştırmaları Dergisi, 22(3), 615-644.

Dayınlarlı, K. (1990). Dış Ticaret İşlemlerinde Akreditif. Yargıtay Dergisi, (3), 406-423.

Doğan, V. (2005). Uluslararası Ticarette Ödeme Aracı Olarak Akreditif. Ankara: Seçkin Yayınları. Ekici, A. (1995). Akreditifin Hukuki Niteliği ve Taraflarn Yükümlülükleri. İstanbul: Beta Yayınları.

Erdoğan, İ. (2000). Akreditif Sözleşmeleri. Ankara: Nobel Yayın Dağıtım.

Göğer, E. (1980). Akreditif Muamelesi ve Hukukî Mahiyeti. Ankara: Banka ve Ticaret Hukuku Araştırma Enstitüsü Yayınları.

Kaya, A. (1995). Belgeli Akreditifte Lehtarın Hukukî Durumu. İstanbul: Beta Yayınları.

Kostakoğlu, C. (2010). Akreditif. İstanbul: Beta Yayınları.

Özel, S. (2013). Akreditif İlişskisinde UTO Kurallarının (UCP 600) Bankalar Arası İlişkiye Etkisi. TürkÇin Hukuk Zirvesi, 12-14 Haziran 2012. İstanbul: Adalet Yayınevi.

Özel, S. (1991). Akreditif ve Hukuki Niteliği. İstanbul: Beta Yayınları.

Reisoğlu, S. (1995). Türk Hukuku'nda ve Bankacılık Uygulamasında Akreditif. Ankara.

Somuncuoğlu, Ü. (2001). Akreditif Hukukunun Genel Hükümleri, İstanbul: Milsan Yayınevi.

Tekinalp, U். (2009). Banka Hukukunun Esaslan. İstanbul: Vedat Kitapç1lık.

Uluç, M. R. (1966). Borçlar Hukuku Açısından Akreditif. Banka ve Ticaret Hukuku Dergisi, 3(3), 432478. 